\title{
Antidiabetic activity of Trichosanthes cucumerina in normal and streptozotocin-induced diabetic rats
}

\author{
Menuka ARAWWAWALA ${ }^{1 *}$, Ira THABREW $^{2}$ and Lakshmi ARAMBEWELA ${ }^{1}$ \\ ${ }^{1}$ Industrial Technology Institute, Bauddhaloka Mawatha, Colombo 07, Sri Lanka. \\ ${ }^{2}$ Institute of Biochemistry, Molecular Biology and Biotechnology, University of Colombo, \\ No. 90, Cumaratunga Munidasa Mawatha, Colombo 3, Sri Lanka. \\ Corresponding author,E-mail: menuka@iti.lk
}

\begin{abstract}
Aerial parts of Trichosanthes cucumerina (Family: Cucurbitaceae) are used in traditional medical systems for treatment of diabetes and other diseases. The present study was designed to experimentally evaluate the antidiabetic potential of a hot water extract (HWE) of T. cucumerina (TC) aerial parts. In normoglycemic rats, HWE mediated (a) a dose dependent reduction in fasting blood glucose (FBS) levels (by $35 \%$ at $4 \mathrm{~h}$ post-treatment with dose of $750 \mathrm{mg} / \mathrm{kg})$ and (b) a significant $(\mathrm{P}<0.05)$ improvement of glucose tolerance. In STZ-induced diabetic rats, no immediate hypoglycemic effect was observed. However, with continuous administration, there was a gradual reduction in FBS (by $56.8 \%$ on day 14 and by $64.4 \%$ on day 28). In normoglycemic rats, on day 14 and day 28, the percentage reduction in FBS levels were $41 \%$ and $44 \%$ respectively. At the end of 28 days, in both normoglycemic and STZ-induced diabetic rats, there was a significant increase in the levels of liver glycogen and adipose tissue triglyceride levels, in comparison with the respective controls that did not receive HWE. However, HWE failed to inhibit intestinal glucose uptake. It may be concluded that T.C can exert significant antidiabetic activity, possibly through multiple effects involving pancreatic and extra pancreatic mechanisms.

(C) 2009 International Formulae Group. All rights reserved.
\end{abstract}

Key words: Cucurbitaceae, hypoglycemic activity, glucose tolerance, triglyceride, glycogen.

\section{INTRODUCTION}

Diabetes Mellitus is a chronic metabolic disorder affecting approximately $4 \%$ population worldwide and is expected to increase by $5.4 \%$ in 2025 (Kim et al., 2006). It is characterized by abnormalities in carbohydrate, lipid and lipoprotein metabolism, which not only lead to hyperglycemia but also cause many complications such hyperlipidemia, hyperinsulinemia, hypertension and atherosclerosis (Chait and Brunzell, 1996; Watkins, 2003). Before the discovery of insulin in 1922, the only treatment options for diabetes were those based on traditional practices. Ethnobotanical knowledge played a particularly important role in historical diabetes therapies, with over 1200 species of medicinal plants recognized throughout the world for their ability to treat diabetic indications (Marles and Farnsworth, 1995; Kim et al., 2006). In Sri Lanka also, aqueous extracts of several plant species are recommended for the control of blood glucose levels in diabetic patients (Tissera and Thabrew, 2001), despite paucity of evidence from scientifically controlled trials to validate the claimed therapeutic effects or to determine potential risks of treatment with such products.

Trichosanthes cucumerina Linn is an annual, dioecious climber belonging to the family Curcurbitaceae. It is widely distributed in Asian countries including Sri Lanka, India, Malay Penisula and Philippine (Jayaweera, 1980). The whole plant including roots, 
leaves, fruits, seeds have medicinal properties. The root is used as a cure for bronchitis, headache and boils. Externally, the leaf juice is rubbed over the liver to relieve liver congestion. Both the root and fruit are considered to be cathartic. The fruit is used as an anthelmintic in French Guiana. The seeds are used for stomach disorders in Malabar Coast and are also considered antifebrile and anthelmintic. The aerial parts of $T$. cucumerina are used along with other plant materials for indigestion, bilious fevers, boils, sores, skin eruptions such as eczema, dermatitis, psoriasis, ulcers and diabetes (Anonymous, 1976; Jayaweera, 1980; Anonymous, 2002). A few studies have been conducted to investigate the properties of galactose specific seed lectin of $T$. cucumerina. These include the thermodynamic and kinetic analysis of porphyrin binding studies (Kenoth et al., 2001), physicochemical and saccharide binding properties (Kenoth et al., 2003) and steadystate and time-resolved fluorescence studies of the seed (Kenoth and Swamy, 2003). Studies on the pharmacological activities have shown the presence of antiinflammatory activity in root tubers (Kolte et al., 1996, 1997) and antidiabetic activity in seeds (Kar et al., 2003) of T. cucumerina. According to Kar and co-workers (2003), an ethanolic extract of T. cucumerina seeds significantly reduces blood glucose levels of alloxan-induced diabetic rats. However, in the traditional medicinal systems of Sri Lanka, it is the aerial parts of T. cucumerina that are used for the therapeutic purposes; this plant is one of the major ingredient in a poly herbal preparations that is prescribed to diabetic patients (Anonymous, 1976; Jayaweera, 1980; Anonymous, 2002). However, the antidiabetic potential of $T$. cucumerina has not been validated by scientifically controlled investigations. Therefore, the present study was conducted to investigate the antidiabetic activity of $T$. cucumerina aerial parts, using Wistar rats as the experimental model. Both normoglycemic and streptozotocin (STZ)induced diabetic rats were used for the investigation.

\section{MATERIALS AND METHODS \\ Plant material}

T. cucumerina plants were collected from Western province of Sri Lanka. The plant was identified and authenticated by the curator of National Herbarium, Royal Botanical Gardens, Peradeniya, Sri Lanka. A voucher specimen (TS 01) was deposited in the Industrial Technology Institute, Colombo 7, Sri Lanka.

\section{Animals}

Healthy adult male and female Wistar rats (weighing $200 \mathrm{~g}-225 \mathrm{~g}$ ) were used throughout the experimental period. They were housed under standardized animal house conditions and fed with standard rat feed prepared by the Medical Research Institute, Sri Lanka according to W.H.O. standards and water ad libitum. All animal experiments were conducted in accordance with the internationally accepted laboratory animal use and care and guide lines and rules of the ethical committee, University of Kelaniya, for animal experimentations.

\section{Preparation of hot water extract (HWE)}

T. cucumerina aerial parts were cut into small pieces and air-dried. Then, $60 \mathrm{~g}$ of the plant material was boiled in $1.9 \mathrm{l}$ of distilled water (DW) and the final volume was reduced to $240 \mathrm{ml}$ by gently boiling over $4 \mathrm{~h}$. The hot water extract was freeze-dried and stored at $4{ }^{\circ} \mathrm{C}$ until use (yield $12.5 \%$ dry weight basis).

\section{Administration of extract \\ Doses of 375, 500, 750 and 1000 $\mathrm{mg} / \mathrm{kg}$ of HWE were administered orally by gastric gavage (each dose in a volume of $1 \mathrm{ml}$ DW) to separate groups of rats. The dose of $750 \mathrm{mg} / \mathrm{kg}$ corresponds to the normal therapeutic dose administered to adult humans as calculated on the basis of relative surface areas of humans and rats (Paget and Barnes, 1996).}

\section{Standardization of HWE}

For standardization of the HWE, (a) phytochemical screening and (b) estimation of total polyphenolic and flavonoid contents were carried out according to methods described below.

\section{Phytochemical screening of HWE}

Qualitative testing of the HWE for alkaloids, polyphenols, flavonoids, steroids, saponins and tannins was carried out 
according to the method described by Farnsworth (1996).

Quantitative determination of total polyphenolic content in HWE

The total polyphenolic content was estimated according to the Folin-Ciocalteu method described by Spanos and Worlstad (1990). Known concentrations of HWE (0.1 $\mathrm{ml})$ was diluted with DW $(0.9 \mathrm{ml})$ and mixed with $5 \mathrm{ml}$ of 10 fold diluted solution of FolinCiocalteu reagent. Four milliliters of saturated sodium carbonate solution was added to the above mixture and shaken. The absorbance of the reaction mixture was measured at $\lambda 765$ $\mathrm{nm}$ after $2 \mathrm{~h}$. Total phenolic content was expressed as gallic acid equivalents (mg gallic acid/g extract).

\section{Quantitative determination of total flavonoid content in HWE}

The total flavonoid content was determined using the Dowd method as described by Meda et al. (2005). In this experiment, $5 \mathrm{ml}$ of $2 \% \mathrm{AlCl}_{3}$ in methanol was mixed with the same volume of the plant extract in known concentrations. After 10 min. the absorbance of the reaction mixture was measured at $\lambda 415 \mathrm{~nm}$. Total flavonoid content was expressed as quercetin equivalents (mg quercetin/g extract).

\section{Experimental design}

Acute effect of $\mathrm{HWE}$ on fasting blood glucose levels in normoglycemic rats

Seventy two rats were fasted overnight for $12 \mathrm{~h}$ and using aseptic precautions, under ether anesthesia, blood was collected from their tails. Immediately afterwards, these rats were divided randomly into 6 groups (female $\mathrm{n}=6$, male $=6$ /group) and treated orally in the following manner: each rat in group1 received $1 \mathrm{ml}$ of DW (control group). Groups 2, 3, 4 and 5 received 375, 500, 750 and 1000 $\mathrm{mg} / \mathrm{kg}$ of HWE respectively. Group 6 received $75 \mathrm{mg} / \mathrm{kg}$ of tolbutamide (reference drug). Blood samples were collected from the tails 2 $\mathrm{h}, 4 \mathrm{~h}$ and $6 \mathrm{~h}$ post treatment with DW or plant extract, for the determination of serum glucose levels.

\section{Effect of HWE on oral glucose tolerance in normoglycemic rats}

This was investigated using $750 \mathrm{mg} / \mathrm{kg}$ of HWE since this dose corresponds to the dose that produced the maximum decrease of the fasted blood glucose levels in normoglycemic and STZ-induced diabetic rats and also corresponds to the normal therapeutic dose in humans. In brief, thirty six rats were fasted for $12 \mathrm{~h}$ and assigned randomly into 3 equal groups (female $n=6$, male $=6 /$ group). These rats were orally treated in the following manner: each rat in group1 received $1 \mathrm{ml}$ of DW (control group), group 2 received $750 \mathrm{mg} / \mathrm{kg}$ of HWE and group 3 received $75 \mathrm{mg} / \mathrm{kg}$ of tolbutamide (reference drug). Thirty minutes, after the administration of drugs, all these rats were orally loaded with $10 \mathrm{ml} / \mathrm{kg}$ of $50 \%(\mathrm{w} / \mathrm{v})$ glucose solution. Blood samples were collected from the tails of these rats and the blood glucose levels determined immediately prior to commencement of treatment and at hourly intervals up to $5 \mathrm{~h}$ after glucose challenge.

Sub-chronic effect of $\mathrm{HWE}$ on fasting blood glucose levels in normoglycemic rats

Twenty four rats were fasted for $12 \mathrm{~h}$ and assigned randomly into 2 equal groups (female $\mathrm{n}=6$, male $=6 /$ group). These rats were orally treated in the following manner: each rat in group1 received $1 \mathrm{ml}$ of DW (control group) while rats in group 2 received $750 \mathrm{mg} / \mathrm{kg}$ of HWE for 28 consecutive days. Rats were fasted for $12 \mathrm{~h}$ and blood samples collected from the tails on day 14 and day 28 post - treatment for determination of serum glucose levels.

Acute and sub-chronic effects of HWE on blood glucose level in streptozotocin (STZ)induced diabetic rats

A dose of $750 \mathrm{mg} / \mathrm{kg}$ was used in this experiment, in order to compare the acute and sub-chronic effects of the HWE in normoglycemic and STZ-induced diabetic rats. STZ (Sigma Chemical Company St. Louis MO, USA) was dissolved in $0.1 \mathrm{M}$ cold citrate buffer $(\mathrm{pH}=4.5)$ Immediately afterwards, $50 \mathrm{mg} / \mathrm{kg}$ dose of STZ was injected to the tail vein of the rat under mild ether anesthesia with aseptic precautions (MacSweeney, 1995). Three days later, rats were fasted for $12 \mathrm{~h}$, blood samples were collected from the tails and glucose levels were determined. Rats having blood glucose level > $200 \mathrm{mg} / \mathrm{dl}$ were selected. For further studies, these rats were assigned randomly into two equal groups (female $\mathrm{n}=4$, male $=$ 3/group) and treated in the following manner: each rat in group1 received $1 \mathrm{ml}$ of $\mathrm{DW}$ 
(control group) and group 2 received 750 $\mathrm{mg} / \mathrm{kg}$ of HWE. Blood samples were then collected from the tails of these rats $2 \mathrm{~h}$ and 4 $\mathrm{h}$ post-treatment and serum glucose levels were determined in order to investigate the acute effect of HWE in STZ-induced diabetic rats. Treatments with HWE or DW were continued for further 28 consecutive days. Rats were fasted for $12 \mathrm{~h}$ and blood samples collected from the tails on day 14 and day 28 post-treatment for determination of serum glucose levels.

\section{Blood glucose estimation}

In all these experiments approximately $1 \mathrm{ml}$ blood was drawn each time from the tail using aseptic precautions and serum was separated immediately by centrifuging at 3000 rpm for $15 \mathrm{~min}$. The glucose concentration in the serum samples was analyzed immediately by the glucose oxidase method using Randox assay kit (Randox Laboratories Ltd., Co. Antrium, UK).

Determination of the possible mechanisms by which antidiabetic activity is mediated

For determination of the mechanisms by which the HWE exerts antidiabetic activity, its effects on (a) intestinal glucose uptake and (b) extra-pancreatic effects (liver glycogen and adipose tissue triglyceride levels), were assessed by methods described below. In these experiments, $750 \mathrm{mg} / \mathrm{kg}$ of HWE was used as this dose corresponds to the normal therapeutic dose administered to adult humans as calculated on the basis of relative surface areas of humans and rats (Paget and Barnes, 1996).

Effect on glucose absorption from intestine

Twelve rats were fasted for $12 \mathrm{~h}$ and divided randomly into two equal groups (female $n=3$, male $n=3$ /group). The dose of $750 \mathrm{mg} / \mathrm{kg}$ of HWE was orally administered to one group and $1 \mathrm{ml}$ of $\mathrm{DW}$ to the other group. Thirty minutes later, $10 \mathrm{ml} / \mathrm{kg}$ of $50 \%$ glucose solution was given orally. After $4 \mathrm{~h}$, these rats were sacrificed and their small intestines exposed. Fifty milliliters of DW was then infused from one cut end of the intestine and the content was collected at the other end. This was centrifuged at $3000 \mathrm{rpm}$ for $5 \mathrm{~min}$. and supernatant discarded. Glucose level in the supernatant was then estimated by the glucose oxidase method using a Randox assay kit (Ratnasooriya et al., 2004).
Investigation of extra-pancreatic effects in normoglycemic rats and STZ-induced diabetic rats

The glycogen content in the liver and triglyceride level in the adipose tissue were determined using the normoglycemic rats and STZ-induced diabetic rats that were treated with HWE or DW for 28 consecutive days. On day 1 post treatment, rats were sacrificed; each liver was removed, dried on tissue paper and stored at $-20{ }^{\circ} \mathrm{C}$ for the assessment of liver glycogen content. For triglyceride estimation, samples of adipose tissue were excised and stored at $-20{ }^{\circ} \mathrm{C}$.

Determination of glycogen content in liver tissue

Glycogen content was determined using a spectrophotometric method as described by Borst et al. (2000). Briefly, 100 $\mathrm{mg}$ of each organ was digested with $2 \mathrm{ml}$ of $30 \%$ boiling $\mathrm{KOH}$, and cooled. Three milliliters of $95 \%$ ethanol was added and heated until bubbles were formed. The mixtures were then cooled and centrifuged (at $1000 \mathrm{rpm}$ for $5 \mathrm{~min}$.) and supernatant discarded. The residue was dissolved in $5 \mathrm{ml}$ of DW. Four milliliters of anthrone reagent was added to these solutions and the tubes immersed in an ice bath, to prevent excessive heating. Tubes were then incubated at $100{ }^{\circ} \mathrm{C}$ for $4 \mathrm{~min}$. for color development, cooled in an ice bath and absorbance of solutions measured at $\lambda 620 \mathrm{~nm}$ using a spectrophotometer (Shimadzu, UV - 1601).

\section{Determination of triglyceride levels in} adipose tissue

For triglyceride estimations, samples of adipose tissue $(100 \mathrm{mg}$ each $)$ were homogenized in isopropanol $(4 \mathrm{ml})$ and centrifuged. The supernatant was then mixed well with $4 \mathrm{ml}$ of isopropanol and the triglyceride content in the mixture assayed by a colorimetric method (Varley et al., 1980) based on the Hantzsch reaction as described by Fernando et al. (1998).

\section{Statistical analysis}

Data are presented as means \pm S.E.M. Statistical comparisons were made using one way ANOVA followed by Tukey's family error test. A $P$ value $<0.05$ was considered as significant. Dose dependencies were determined by regression coefficients $\left(\mathrm{r}^{2}\right)$. 
RESULTS

Phytochemical screening of HWE

Phytochemical screening revealed the presence of alkaloids, polyphenols, flavonoids, steroids, saponins and tanins in the extract.

Total polyphenol and flavonoid content in HWE

The mean total polyphenolic content and flavonoid content of 3 samples of HWE were $65.8 \pm 0.50 \mathrm{mg}$ gallic acid equivalents $/ \mathrm{g}$ extract and $45.4 \pm 0.76 \mathrm{mg}$ quercetin equivalents/g extract respectively.

Effect on fasting blood glucose levels in normoglycemic rats

The effects of $T$. cucumerina HWE on the fasting blood glucose levels in normoglycemic rats are shown in table 1 . All doses of HWE significantly $(\mathrm{P}<0.05)$ reduced the blood glucose levels up to $6 \mathrm{~h}$ except the lowest dose. This impairment of blood glucose levels of HWE was marked and dose dependent $\left(\mathrm{r}^{2}=\right.$ second hour 1 , fourth hour 1 ; sixth hour 1) at each time point. The maximum hypoglycemic activity was induced by $750 \mathrm{mg} / \mathrm{kg}$ dose at $4 \mathrm{~h}$ (by 35\%). Hypoglycemic effect of tolbutamide, the reference drug, was comparable to $750 \mathrm{mg} / \mathrm{kg}$ dose of HWE at $4 \mathrm{~h}$. However, the effects of other tested doses of T. cucumerina extracts were inferior to the reference drug.

Effect on glucose tolerance in normoglycemic rats

HWE significantly $(\mathrm{P}<0.05)$ improved the glucose tolerance up to $5 \mathrm{~h}$ (Table 2), showing approximately $17 \%, 12 \%, 11 \%, 8 \%$ and $10 \%$ reduction in glycemia from control values at the 1,2,3,4 and $5 \mathrm{~h}$ respectively. Tolbutamide also improved the glucose tolerance test up to $5 \mathrm{~h}$. The effect of $T$. cucumerina HWE was comparable to that of the reference drug, tolbutamide.

\section{Sub-chronic effect on fasting blood glucose levels in normoglycemic rats}

Sub-chronic treatment with HWE significantly $(\mathrm{P}<0.05)$ reduced the serum glucose level on day 14 by $41 \%$ (control versus treatment; $90.0 \pm 1.9$ versus $52.9 \pm 2.4$ $\mathrm{mg} / \mathrm{dl}$ ) and on day 28 by $44 \%$ (control versus treatment $88.5 \pm 1.8$ versus $49.1 \pm 2.7 \mathrm{mg} / \mathrm{dl}$ ).
Acute and sub-chronic effect on fasting blood glucose level in STZ-induced diabetic rats

The results are summarized in Table 3 . As shown, there was no immediate antihyperglycemic effect observed. However, with continuous administration of the HWE there was a gradual reduction in the fasting blood glucose levels observed after 28 days of treatment (by $56.8 \%$ on day 14 and on day 28 by $64.4 \%)$.

\section{Effect on glucose absorption from intestine}

HWE treatment did not significantly $(\mathrm{P}>0.05)$ inhibit the glucose absorption from the lumen of the intestine in the test rats (control versus treatment: $38.1 \pm 3.0$ versus $44.6 \pm 1.9 \mathrm{mg} / \mathrm{dl})$.

Effect on liver glycogen content and triglyceride level on adipose tissue

As shown in Table 4, glycogen content in liver and triglycerides in adipose tissue were significantly $(\mathrm{P}<0.05)$ increased in both normoglycemic and STZ-induced diabetic rats on administration of the HWE.

\section{DISCUSSION}

Overall results of the present investigation demonstrate that the HWE of T. cucumerina aerial parts can significantly reduce the blood glucose levels and improve the glucose tolerance of normoglycemic and STZ-induced diabetic rats. These results provide scientific evidence in support of the antidiabetic potential of $T$. cucumerina and help to rationalize the traditional use of this plant for the treatment of diabetic patients (Anonymous, 1976; Jayaweera, 1980; Anonymous, 2002).

In accordance with known mechanisms of action of oral hypoglycemic agents (Watkins, 2003; Mogensen, 2007), the hypoglycemic activity of $T$. cucumerina HWE could be due to one or more of the following mechanisms: (a) induction of the $\beta$-cells of the islets of Langerhans to secrete insulin (b) direct increase in the peripheral utilization of glucose (c) inhibition of intestinal glucose absorption or (d) inactivation of an endogenous insulin inhibitor. According to results obtained in the present investigation, $T$. cucumerina failed to inhibit glucose 
Table 1: Effect of hot water extract (HWE) of Trichosanthes cucumerina on serum glucose levels in normoglycemic rats.

\begin{tabular}{lcccc}
\hline \multirow{2}{*}{ Groups } & \multicolumn{4}{c}{ Serum glucose levels (mg/d) with time } \\
\cline { 2 - 5 } & pre-treatment & $\mathbf{2 ~ h}$ & $\mathbf{4 ~ h}$ & $\mathbf{6 ~ h}$ \\
\hline Control & $90.6 \pm 2.4$ & $89.0 \pm 1.9$ & $91.6 \pm 2.1$ & $93.2 \pm 1.4$ \\
$(1 \mathrm{ml}$ of distilled Water) & $93.1 \pm 2.5$ & $92.4 \pm 1.8$ & $92.5 \pm 2.3$ & $92.4 \pm 2.3$ \\
$375 \mathrm{mg} / \mathrm{kg}$ of HWE & $91.8 \pm 1.9$ & $70.3 \pm 1.3^{*}$ & $66.9 \pm 2.2^{*}$ & $78.0 \pm 1.5^{*}$ \\
$500 \mathrm{mg} / \mathrm{kg}$ of HWE & $90.8 \pm 1.5$ & $63.0 \pm 1.9^{*}$ & $59.2 \pm 1.2^{*}$ & $62.6 \pm 1.2^{*}$ \\
$750 \mathrm{mg} / \mathrm{kg}$ of HWE & $95.0 \pm 2.3$ & $67.8 \pm 1.5^{*}$ & $62.1 \pm 1.8^{*}$ & $69.4 \pm 1.9^{*}$ \\
$1000 \mathrm{mg} / \mathrm{kg}$ of HWE & $92.5 \pm 1.8$ & $49.7 \pm 1.5^{*}$ & $55.7 \pm 1.5^{*}$ & $62.4 \pm 1.8^{*}$ \\
Tolbutamide $(75 \mathrm{mg} / \mathrm{kg})$ & \multicolumn{4}{c}{ Results are expressed as the means $\pm \mathrm{SEM}, \mathrm{n}=12^{*}$ Significant at $P<0.05$ relative to controls. }
\end{tabular}

Table 2: Effect of hot water extract (HWE) of Trichosanthes cucumerina on glucose tolerance in normoglycemic rats.

\begin{tabular}{lcccccc}
\hline \multirow{2}{*}{ Groups } & \multicolumn{5}{c}{ Serum glucose levels (mg/dl) at hourly intervals } \\
\cline { 2 - 6 } & $\begin{array}{c}\text { Pre- } \\
\text { treatment }\end{array}$ & $\mathbf{1 ~ h}$ & $\mathbf{2 ~ h}$ & $\mathbf{3 ~ h}$ & $\mathbf{4 ~ h}$ & $\mathbf{5}$ h \\
\hline $\begin{array}{l}\text { Control }(1 \mathrm{ml} \text { of } \\
\text { Distilled water) }\end{array}$ & $88.3 \pm 2.2$ & $159.2 \pm 4.4$ & $145.5 \pm 4.1$ & $134.8 \pm 4.3$ & $122.7 \pm 2.8$ & $112.8 \pm 3.8$ \\
$\begin{array}{l}750 \mathrm{mg} / \mathrm{kg} \\
\text { of HWE }\end{array}$ & $90.8 \pm 2.3$ & $132.7 . \pm 3.9^{*}$ & $127.7 \pm 3.8^{*}$ & $119.1 \pm 3.4^{*}$ & $113.2 \pm 3.0^{*}$ & $102.9 \pm 2.9^{*}$ \\
$\begin{array}{l}\text { Tolbutamide } \\
(75 \mathrm{mg} / \mathrm{kg})\end{array}$ & $89.4 \pm 2.5$ & $135.2 \pm 2.7^{*}$ & $118.0 \pm 2.8^{*}$ & $116.3 \pm 2.1^{*}$ & $106.6 \pm 3.3^{*}$ & $96.6 \pm 2.6^{*}$ \\
\hline
\end{tabular}

Results are expressed as the means \pm SEM, $\mathrm{n}=12,{ }^{*}$ Significant at $P<0.05$ relative to controls.

Table 3: Effect of hot water extract (HWE) of Trichosanthes cucumerina on serum glucose levels in STZ-induced diabetic rats.

\begin{tabular}{lcc}
\hline & Control Group(1 ml of DW) & Test Group (750 $\mathbf{~ m g} / \mathbf{k g}$ of $\mathbf{~ H W E})$ \\
\hline $\begin{array}{l}\text { Initial blood glucose } \\
\text { level (mg/dl) }\end{array}$ & $235.3 \pm 7.2$ & $237.7 \pm 4.4$ \\
$\begin{array}{l}\text { Blood glucose level after } \\
\text { 2 h post-treatment }\end{array}$ & $237.2 \pm 6.0$ & $235.6 \pm 5.1$ \\
$\begin{array}{l}\text { Blood glucose level after } \\
\text { 4 h post-treatment }\end{array}$ & $240.9 \pm 5.9$ & $232.9 \pm 5.7$ \\
$\begin{array}{l}\text { Blood glucose level } \\
\text { after 14 days (mg/dl) }\end{array}$ & $295.7 \pm 4.4$ & $127.6 \pm 6.3^{*}$ \\
$\begin{array}{l}\text { Blood glucose level } \\
\text { after 28 days (mg/dl) }\end{array}$ & $314.0 \pm 4.8$ & $111.9 \pm 4.8^{*}$ \\
\hline
\end{tabular}

Results are expressed as the means \pm SEM, $\mathrm{n}=7$, ${ }^{*}$ Significant at $P<0.05$ relative to controls

absorption from the lumen of the intestine. Similar results have been reported for many other plants with hypoglycemic effects such as Hygrophila longifolia (Fernando et al., 1998) and Piper betle (Arambewela et al., 2005). The mode of action of T. Cucumerina therefore appears to be different from that of biguanides (Watkins, 2003; Mogensen, 2007) and some other hypoglycemic plants that can reduce intestinal glucose uptake (Bnouham et al., 2003; Ratnasooriya et al., 2004; Beppu et al., 2006; Meddah et al., 2009). On the other hand, results obtained in the present study provide supportive evidence for the view that T. cucumerina exerts its hypoglycemic action by mechanisms similar to those of sulphonylureas (Watkins, 2003; Mogensen, 
Table 4: Extra-pancreatic effects of hot water extract (HWE) of Trichosanthes cucumerina in normoglycemic and STZ-induced diabetic rats at the end of the 28 days experimental period.

\begin{tabular}{lcc}
\hline Treatments & $\begin{array}{c}\text { Glycogen content in } \\
\text { Liver }(\boldsymbol{\mu g} / \mathbf{1 0 0} \mathbf{g})\end{array}$ & $\begin{array}{c}\text { Triglyceride content in } \\
\text { adipose tissue }(\boldsymbol{\mu g} / \mathbf{1 0 0} \mathbf{g})\end{array}$ \\
\hline $\begin{array}{l}\text { Normal Control } \\
(1 \mathrm{ml} \text { of distilled water })\end{array}$ & $80.2 \pm 2.9$ & $443.9 \pm 7.2$ \\
$\begin{array}{l}\text { Normal + } 750 \mathrm{mg} / \mathrm{kg} \\
\text { of HWE }\end{array}$ & $125.0 \pm 6.8^{*}$ & $507.4 \pm 8.0^{*}$ \\
$\begin{array}{l}\text { Diabetic Control } \\
(1 \mathrm{ml} \text { of distilled water })\end{array}$ & $49.3 \pm 4.3$ & $223.1 \pm 6.6$ \\
$\begin{array}{l}\text { Diabetic + } 750 \mathrm{mg} / \mathrm{kg} \\
\text { of HWE }\end{array}$ & $95.4 \pm 3.8^{*}$ & $260.4 \pm 7.4^{*}$ \\
\hline
\end{tabular}

Results are expressed as the means \pm SEM, $*$ Significant at $P<0.05$ relative to controls.

2007). Thus, T. cucumerina had no effect on intestinal glucose absorption while significantly increasing the accumulation of glycogen in the liver and triglycerides in the adipose tissue. Similar mode of action has been observed with other plants such as Hygrophila longifolia (Fernando et al., 1998), Piper betle (Arambewela et al., 2005) Cinnamonum zelanicum (Babu et al., 2007) and Caralluma sinaica (Habibuddin et al., 2008).

Insulin is a stimulator of the glycogen synthase system and when insulin is lacking this enzyme is not activated. On the other hand, insulin inhibits glycogenolysis and if there is a lack of insulin, glycogenolysis is enhanced and the glycogen content of the liver decreases (Vats et al., 2004). Sub-chronic oral administration of $T$. cucumerina HWE significantly increased the hepatic glycogen levels in normoglycemic and STZ-induced diabetic rats.

Lipids play a vital role in the pathogenesis of Diabetes Mellitus. The most common lipid abnormalities in diabetes are hypertriglyceridemia and hypercholesterolemia (Babu et al., 2007). In insulin deficient diabetes, there is an elevated serum triglyceride concentration as a result of free fatty acid outflow from fat depots and reduced lipoprotein lipase activity (Chait and Brunzell, 1996; Shirwaikar et al., 2004). Sub-chronic administration of $T$. cucumerina HWE increased triglyceride levels in the adipose tissues of both normoglycemic and STZinduced diabetic rats compared to the respective control groups. Some other plants such as Hygrophila longifolia (Fernando et al., 1998), Cinnamomum zeylanicum (Roffey et al., 2006) and Guazuma ulmifolia (AlonsoCastro and Salazar-Olivo, 2008) have also been reported to exert similar effects on triglyceride synthesis.

STZ is widely used as a diabetogenic agent in experimental animals (Dimo et al., 2007; Oliveira et al., 2008). The use of a low dose of STZ $(50 \mathrm{mg} / \mathrm{kg})$ produces an incomplete destruction of pancreatic $\beta$-cells even though the rats become permanently diabetic (Aybar et al., 2002). The increased levels of serum glucose in STZ-induced diabetic rats were lowered by $T$. cucumerina extract administration. This ability to lower blood glucose levels of STZ-induced diabetic rats also suggests that HWE may act as an insulin secretagoue and/or sensitize insulin receptors, as proposed for some plant extracts (Chakrabarti et al., 2003; Bakirel et al., 2008) and some sulphonylureas (Campbell, 2000). Further, HWE may as proposed by Gomes and co-workers (2001) with respect to Camellia sinensis (black tea), regenerate the $\beta$-cells in pancreas or protect the intact functional $\beta$-cells from further deterioration so that they remain active and continue to produce insulin. The effects of T. cucumerina HWE on insulin levels of STZ-induced diabetic rats are under investigation.

It is not possible at this stage to definitely conclude whether the HWE mediated increase in glycogen synthesis in liver and triglyceride synthesis in the adipose tissue are due to an increased insulin release form the pancreas, due to a direct effect of the plant extract on target tissues, or both. Further investigations to determine the effects of HWE on insulin release from the pancreas are in progress. 
Recently, much attention has been focused on the role of oxidative stress in diabetes, and it has been suggested that oxidative stress may mediate the key and common events in the pathogenesis of different diabetic complications (SepiciDincel et al., 2007). Human diabetics and experimental diabetic animal models exhibit high oxidative stress due to persistent and chronic hyperglycemia that may result in depletion of the antioxidant defense system and thus lead to an enhanced de novo free radical generation (Kamalakannan and Prince, 2006). Reaction of these free radicals with membrane lipids would result in an increased lipid peroxidation that can be prevented by antioxidants (Sepici-Dincel et al., 2007) including plant phenolic compounds (Coskun et al., 2005).

T. cucumerina HWE can exert significant in vitro (as judged by TBARS assay and DPPH scavenging assay) and in vivo (as judged by serum antioxidant levels in $\mathrm{CCl}_{4}$ induced rats) antioxidant activities (unpublished data). The present investigation has demonstrated that the HWE of $T$. cucumerina is rich in polyphenolic compounds.

Polyphenols are plant compounds that can exert significant antioxidant activity, mainly due to their redox properties (Galato et al., 2001; Zheng and Wang, 2001), which can play an important role in absorbing and neutralizing free radicals, quenching singlet and triplet oxygen or decomposing peroxides. Therefore, antioxidant compounds present in HWE may also play a major role in mediating the antidiabetic effects of $T$. cucumerina. Phenolic compounds (e.g. flavonoids, tannins) have also been reported to exhibit antidiabetic activity (Iwu, 1983; Ahmad et al., 2000; Coskun et al., 2005; Quintanar-Isaias et al., 2005) and are also known for their ability to assist in regeneration of $\beta$-cells of the pancreas (Chakravarthi et al., 1980, 1981; Coskun et al., 2005). Thus, the significant antidiabetic effect of $T$. cucumerina HWE may be due to the presence of more than one antihyperglycemic principle and their synergistic effects.

From the overall results obtained in the present investigation it may be concluded that T. cucumerina HWE has antidiabetic potential, and can exert significant hypoglycemic and antihyperglycemic activities possibly through multiple effects involving both pancreatic and extrapancreatic mechanisms.

\section{ACKNOWLEDGEMENTS}

National Science Foundation for the Research Grant NSF/SCH/2005/13.

\section{REFERENCES}

Ahmad M, Akhtar MS, Malik T, Gilani AH. 2000. Hypoglycemic action of the flavonoid fraction of Cuminum nigrum seeds. Phytother. Res., 14: 103 - 106.

Alonso-Castro AJ, Salazar-Olivo LA. 2008. The antidiabetic properties of Guazuma ulmifolia Lam are mediated by the stimulation of glucose uptake in normal and diabetic adipocytes without inducing adipogenesis. J. Ethnopharmacol., 118: $252-256$.

Anonymous. 1976. The Wealth of India. The Dictionary of Indian Raw Materials and Industrial Products (Vol. 10). Publication and Information directorate, CSIR: New Delhi; 291.

Anonymous. 2002. Compendium of Medicinal Plants (Vol. 2). A Publication of Department of Ayurveda: Sri Lanka; 146-150.

Arambewela LSR, Arawwawala LDAM, Ratnasooriya WD. 2005. Antidiabetic activities of aqueous and ethanolic extracts of Piper betle leaves in rats. $J$. Ethnopharmacol., 102: 239 - 245.

Aybar M, Sanchez RAN, Grau A, Sanchez SS. 2002. Hypoglycemic effect of water extract of Smallanthus soncifolius (yacon) leaves in normal and diabetic rats. J. Ethnopharmacol., 74: 125-132.

Babu PS, Prabuseenivasan S, Ignacimuthu S. 2007. Cinnamaldehyde - A potential antidiabetic agent. Phytomedicine, 14: 15-22.

Bakirel T, Bakirel U, Keles OU, Ulgen SG, Yardibi H. 2008. In vivo assessment of antidiabetic and antioxidant activities of rosemary (Rosmarinus officinalis) in alloxan-diabetic rabbits. J. Ethnopharmacol., 116: $64-73$.

Beppu H, Shimpo K, Chihara T, Kaneko T, Tamai I, Yamaji S, Ozaki S, Kuzuya H, Sonoda S. 2006. Antidiabetic effects of dietary administration of Aloe arborescens Miller components on 
multiple low-dose streptozotocininduced diabetes in mice: Investigation on hypoglycemic action and systematic absorption dynamics of aloe components. J. Ethnopharmacol., 103: $468-477$.

Bnouham M, Merhfour FZ, Ziyyat A, Mekhfi H, Aziz M, Legssyer A. 2003. Antihyperglycemic activity of the aqueous extract of Urtica dioica. Fitoterapia, 74: 677 - 681 .

Borst SE, Snellen HG, Lai HL. 2000. Metformin treatment enhances insulinstimulated glucose transport in skeletal muscle of Sprague Dawley rats. Life Sci., 67: $165-174$.

Campbell IW. 2000. Antidiabetic drugs present and future: will improving insulin resistance benefit cardiovascular risk in type 2 diabetes mellitus? Drugs, 60: 1017-1028.

Chait A, Brunzell JD. 1996. Diabetes, lipids and atherosclerosis. In Diabetes Mellitus, Le Roith D, Taylor SI, Olefsky JM (ed). Lippincott-Raven Publishers: Philadelphia; $467-469$.

Chakravarthi BK, Gupta S, Gambir SS, Gode KD. 1980. Pancreatic beta cell regeneration. A novel antidiabetic mechanism of Pterocarpus marsupium Roxb. Indian J. Pharmacol., 12: 123 127.

Chakravarthi BK, Gupta S, Gambir SS, Gode KD. 1981. Pancreatic beta cell regeneration in rats by (-) epicatechin. The Lancet, 2: 759 - 760 .

Chakrabarti S, Biswas TK, Rokeya B, Mosihuzzaman M, Ali L, Nahar N, Mukherjee B. 2003. Advanced studies on hypoglycemic effect of Caesalpinia bonducella $\mathrm{F}$. in type 1 and 2 diabetes in Long - Evans rats. J. Ethnopharmacol., 84: $41-46$.

Coskun O, Kanter M, Korkmaz A, Oter S. 2005. Quercetin, a flavonoid antioxidant, prevents and protects streptozotocininduced oxidative stress and $\beta$-cell damage in rat pancreas. Pharmacol. Res., 51: $117-123$.

Dimo T, Rakotonirina SV, Tan PV, Azay J, Dongo E, Kamtchouing P, Cros G. 2007. Effects of Sclerocarya birrea (Anacardiaceae) stem bark methylene chloride/methanol extract on streptozotocin-diabetic rats. J. Ethnopharmacol., 110: $434-438$.

Farnsworth NR. 1996. Biological and phytochemical screening of plants. $J$. Pharm. Sci., 55: 225-276.

Fernando MR, Wickramasinghe SMDN, Thabrew MI. 1998. Extra pancreatic actions of Hygrophila longifolia. Pharmaceut. Biol., 36: 352 - 356.

Galato D, Ckless K, Susin MF, Giacomelli C, Ribeiro de VRM, Spinelli A. 2001. Antioxidant capacity of phenolic and related compounds: correlation among electrochemical, visible spectroscopy methods and structural antioxidant activity. Redox Report, 6: 243 - 250 .

Gomes A, Vedasiromoni JR, Das M, Sharma RM, Ganguly DK. 2001. Antihyperglycemic effect of black tea (Camellia sinensis) in rat. $J$. Ethnopharmacol., 27: 243 - 275.

Habibuddin M, Daghriri HA, Humaira T, Qahtani MSA, Hefzi AAH. 2008. Antidiabetic effect of alcohol extract of Caralluma sinaica L. on streptozotocin induced diabetic rabbits. J. Ethnopharmacol., 117: 215 - 220.

Iwu MM. 1983. Hypoglycemic properties of Bridelia ferruginea leaves. Fitoterapia, 54: $282-285$.

Jayaweera DMA. 1980. Medicinal Plants (Indigenous and Exotic) Used in Ceylon (Part 2). A publication of the National Science Council of Sri Lanka; 162-163.

Kamalakannan N, Prince PSM. 2006. Antihyperglycemic and antioxidant effects of rutin, a polyphenol flavonoid, in streptozotocin-induced diabetic wistar rats. Basic Clin. Pharmacol. Toxicol., 98: $97-103$.

Kar A, Choudhary BK, Bandyopadhyay NG. 2003. Comparative evaluation of hypoglycemic activity of some Indian medicinal plants in alloxan diabetic rats. J. Ethnopharmacol., 84: 105 - 108.

Kenoth R, Raghunath R, Maiya BG, Swamy MJ. 2001. Thermodynamic and kinetic analysis of porphyrin binding to Trichosanthes cucumerina seed lectin. Eur. J. Biochem., 268: 5541 - 5549.

Kenoth R, Komath SS, Swamy MJ. 2003. Physicochemical and saccharidebinding studies on the galactosespecific seed lectin from Trichosanthes 
cucumerina. Arch. Biochem. Biophys., 413: $131-138$.

Kenoth R, GM, Swamy MJ. 2003. Steadystate and time-resolved fluorescence studies on Trichosanthes cucumerina seed lectin. J. Photochem. Photobiol. B. Biol., 69: 193 - 201.

Kim SH, Hyun SH, Choung SY. 2006. Antidiabetic effect of cinnamon extract on blood glucose in $\mathrm{db} / \mathrm{db}$ mice. $J$. Ethnopharmacol., 104: 119 - 123.

Kolte RM, Bisan VV, Jangde CR, Bhalerao AA. 1996-1997. Antiinflammatory activity of root tubers of Trichosanthes cucumerina in mouse's hind paw oedema induced by carrageenin. Indian J. Indigenous Med., 18: 117 - 121.

MacSweeney CP, Kelly JP, Leonard BE. 1995. The influence of route of administration on the diabetogenic effects of streptozotocin in the rats. Med. Sci. Res., 23: 811-812.

Marles RJ, Fransworth NR. 1995. Antidiabetic plants and their active constituents. Phytomedicine, 2: 137-189.

Meda A, Lamien CE, Romito M, Millogo J, Nacoulma OG. 2005. Determination of total phenolic, flavonoid and proline contents in Burkina Fasan honey, as well as their radical scavenging activity. Food Chem., 91: 571 - 577.

Meddah B, Ducroc R, Faouzi MEA, Eto B, Mahraoui L, Benhaddou-Andaloussi A, Martineau LC, Cherrah Y, Haddad PS. 2009. Nigella sativa inhibits intestinal glucose absorption and improves glucose tolerance in rats. J. Ethnopharmacol., 121: $419-424$.

Mogensen CE. 2007. Pharmacotherapy of Diabetes: New Developments, Improving Life and Prognosis for Diabetic Patients. Publication of Springer Science: USA.

Oliveira HC, Santos MPD, Grigulo R, Lima LL, Martins DTO, Lima JCS, Stoppiglia LF, Lopes CF, Kawashita NH. 2008. Antidiabetic activity of Vatairea macrocarpa extract in rats. $J$. Ethnopharmacol., 115: 515 - 519.

Paget GE, Barnes JM. 1996. In Evaluation of Drug Activities : Pharmacometrics (Vol 1), Lawrence DR, Bacharach AL (ed). Academic Press: New York.
Quintanar-Isaias A, Velazquez-Nunez M, Solares-Arenas F, Perez-Olvera C, Torre-Blanco A. 2005. Secondary stem anatomy and uses of four drought deciduous species of a tropical dry forest in Mexico. Rev. Biol. Trop., 53: 29 - 48

Ratnasooriya WD, Hettiarachchi HDI, Jayakody JRAC. 2004. Cassia fistula and hypoglycemia. Aust. J. Med. Herbalism, 16: 8 - 13 .

Roffey B, Atwal A, Kubow S. 2006. Cinnamon water extracts increase glucose uptake but inhibit adiponectin secretion in 3T3 - L1 adipose cells. Mol. Nutr. Food Res., 50: $739-745$.

Sepici-Dincel A, Acikgoz S, Cevik C, Sengelen M, Yesilada E. 2007. Effects of in vivo antioxidant enzyme activities of myrtle oil in normoglycemic and alloxan diabetic rabbits. J. Ethnopharmacol., 110: 498 - 503 .

Shirwaikar A, Rajendran K, Kumar CD, Bodla R. 2004. Antidiabetic activity of aqueous leaf extract of Annona squamosa in streptozotocin-nicotinamide type 2 diabetic rats. $J$. Ethnopharmacol., 91: 171 - 175.

Spanos GA, Worlstad RE. 1990. Influence of processing and storage on the phenolic composition of Thompson seedless grape juice. J. Agric. Food Chem., 38: 15651571.

Tissera MHA, Thabrew MI. 2001. Medicinal plants and ayurvedic preparations containing medicinal plants used in the control of diabetes mellitus. Publication of Department of Ayurveda, Sri Lanka.

Varley H, Gowenlock AH, Bell M. 1980. Practical Clinical Biochemistry (Vol. 1). William Heinemann Medical Books Ltd, UK.

Vats V, Yadav SP, Grover JK. 2004. Ethanolic extract of Ocimum sanctum leaves partially attenuates streptozotocininduced alterations in glycogen content and carbohydrate metabolism in rats. $J$. Ethnopharmacol., 90: 155 - 160.

Watkins PJ. 2003. ABC of Diabetes ( $5^{\text {th }}$ edn). BMJ Publishing Group Ltd, Tavistock Squre: U.K.

Zheng W, Wang SY. 2001. Antioxidant activity and phenolic compounds in selected herbs. J. Agric. Food Chem., 49: $5165-517$. 